胃切除術後に留置された経鼻胃管による残胃穿孔の 1 例

\author{
りんくう総合医療センター市立泉佐野病院外科 \\ 甲斐沼 尚三方彰喜 位藤俊一 \\ 水島恒和野中健太郎 岩 瀬和 裕
}

\begin{abstract}
症例は63歳, 男性. 胃体中部の 3 型胃癌に対して胃要全摘術, Billroth I 法による再建 術を施行し, 残胃内に経鼻胃管を留置した。術後 2 日目より発熱を認め, 血液検查でも 炎症所見の上昇を認めた。腹部 CT 検査を行ったが術後変化による少量の腹水貯留を認 めるのみであった。術後 5 日目, 腹腔内に留置したドレーンより混濁した黄色の排液を 認めたため経鼻胃管を用いた残胃造影検査を施行した。胃管先端が鋳型状に残胃大彎側 から突出し, 造影堉の胃外漏出を認めたため, 胃管による残胃穿孔と診断した。腹腔内 ドレーンによる漏出液のドレナージは良好であったため保存的加療が可能であると判断 し，高カロリー輸液および抗生滆投与を行った，遺残膿煬など他の合併症を併発するこ となく, 術後34日目に経口摄取を開始し, 術後44日目に軽快退院した。
\end{abstract}

索引用語：経鼾胃管, 穿孔, 胃切除術後

\section{はじめに}

消化器手術の術後には経鼻胃管が留置されることが 多い. 本来, 胃・腸内の隇圧を図り術後合併症の予防 を目的として使用されるが, 術後に留置された胃管に よる残胃穿孔の報告も散見される3゙ー7). 胃癌に対する 胃㩊全摘術後に留置した経鼻胃管による残胃穿孔の 1 例を経験したので報告する。

\section{症例}

患者：63歳, 男性.

主訴：下血.

既往歴：20歳時, 虫垂炎にて虫垂切除術.58歳時よ り脳梗塞にて $\alpha$ 遮断薬内服中.

現病歴：平成14年 9 月頃より黒色便を認めるように なり近医を受診.上部消化管内視鏡検査にて胃体中部 前壁の 3 型胃癌を認め, 手術目的にて当科入院となっ た.

手術所見: 平成14年10月幽門側胃切除術, D2 郭清, Billroth I 法にて再建した. 出血量 $400 \mathrm{ml}$ で輸血は行 われなかった. 手術時間は 3 時間20分であった。術中 に16フレンチのポリ塩化ビニル製の胃用サンプチュー

2004年 6 月23日受付 2004 年10月 4 日採用

〈所属施設住所〉

干598-8577 泉佐野市りんくう往来北 $2-23$
ブを経鼻的に残胃に留置した。なお，門歯より胃管先 端までの距離は約 $55 \mathrm{~cm}$ とした。 また, 右側腹部より吻 合部近傍に腹腔内ドレーンを 1 本留置した。

病理所見：胃癌取扱い規約上, $5.0 \times 3.0 \mathrm{~cm}, \mathrm{M}$, Ant, pType3, T2(SS), N1, H0, P0, CY0, M0, stage IIであった。病理組織学的には中分化型腺癌て あった。

術後経過：術後全身状態は安定していたが, 術後 2 日目より $37^{\circ} \mathrm{C}$ 台の発熱を認め, 4 日目に $38.8^{\circ} \mathrm{Cまで上}$ 昇した。炎症所見も徐々に上昇し, 術後 3 日目には白 血球数 $11,000 / \mathrm{mm}^{3}, \mathrm{CRP}$ 値 $35.9 \mathrm{mg} / \mathrm{dl}$ と高值を示し た。腹部に自発痛や腹膜刺激症状は認めず, 緊急に施 行した腹部 CT 検查でも術後変化によると思われる少 量の腹水を認めるのみであり，抗生剤の投与を行いつ つ, 発熱の原因検索を継続した。術後 5 日目, 腹腔内 に留置したドレーンょり混濁した黄色の排液を認めた ため緊急残胃造影検査を施行した。経鼻胃管から造影 棛を少量注入すると抵抗があったため, 約 $3 \mathrm{~cm}$ 引き 抜いて再度造影棛を注入すると, 残胃大鹪側の一部が 胃管先端部の鋳型のように造影され，造影剂の胃外漏 出を認めた（図 1)。CT 検查では胃壁を穿破した胃管 を認めた(図 2 )。また，膵背側部から吻合部周囲を中 心として漏出液が貯留し(図 3), 周囲脂肪織には軽度 の炎症の波及を認めた。 以上の所見から胃管による残 


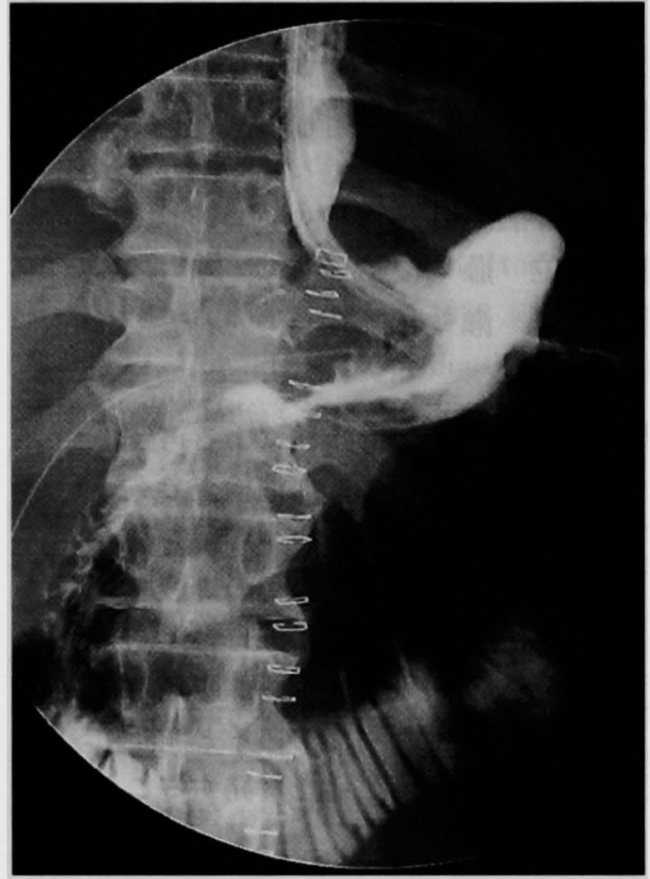

図 1 残胃造影検査：残胃大彎側の一部が胃管 先端部の鋳型のように造影され, 造影剂の胃 外漏出を認めた.

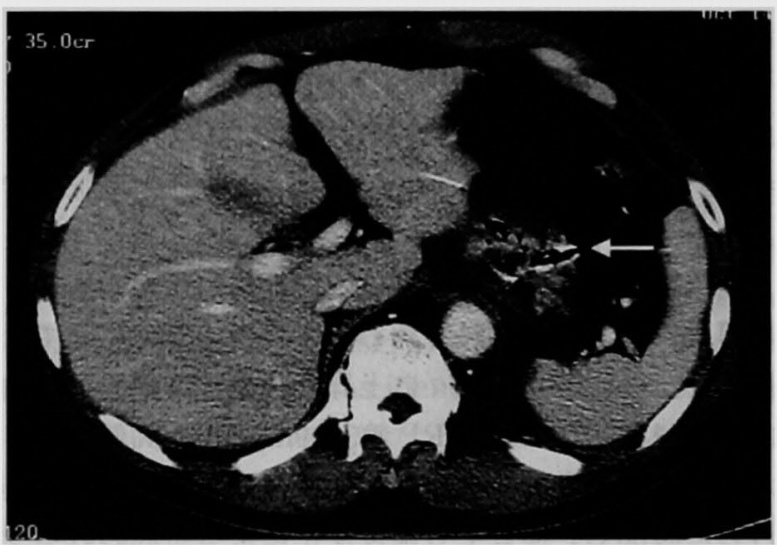

図 2 腹部 CT 検査：胃壁を穿破した胃管を認めた（矢 印).

胃穿孔と診断した。CT 検査上漏出液は限局し, 術中に 留置した腹腔内ドレーンは有効であると判断し, 保存 的治療を行うこととした，絶飲食，高カロリー輸液， 抗生物質投与を開始し, 経鼻胃管は約 $5 \mathrm{~cm}$ 引き抜き, 食道胃移行部直下に留置した。術後12日目に施行した 残胃造影検査で造影剤の胃壁外への漏出は少量であ り,腸管蠕動も良好となったため経鼻胃管を抜去した。 術後19日目の CT 検查では膵背側の漏出液の貯留は消

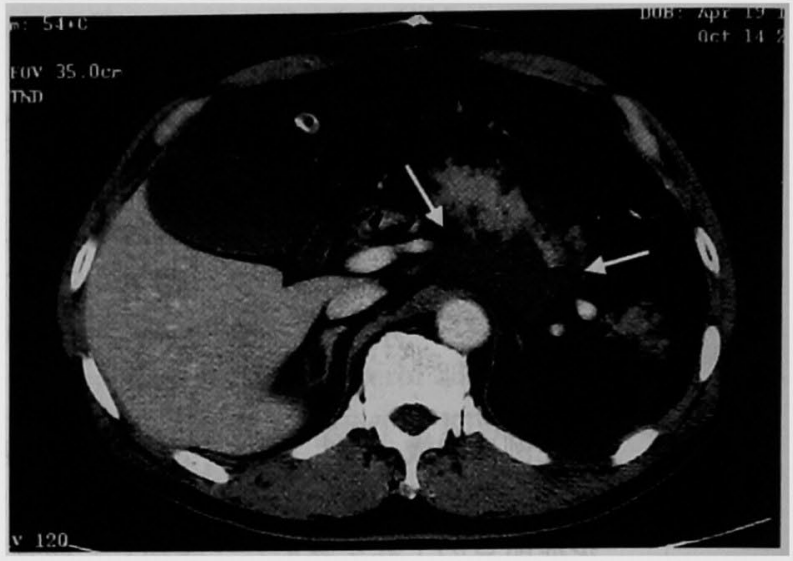

図 3 腹部 CT 検査：漏出液は膵背側部から吻合部周囲 を中心として貯留している (知印).

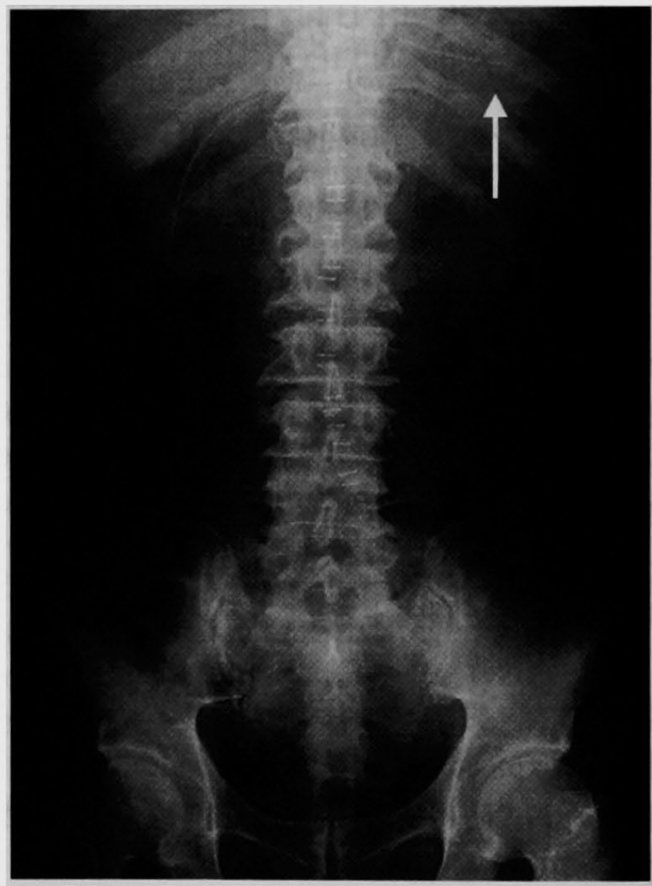

図 4 腹部 $X$ 線検査 (術後 1 日目)：胃管の先端 は左方を向いている (矢印)。

失, 術後27日目に施行した残胃造影検査では造影剤の 胃壁外漏出を少量認めたが，術後34日目の残胃造影検 査では漏出を認めなかった。経口摂取開始後の経過は 良好で術後44日目軽快退院した。

考察

1921年 Levin'1によって初めて考案された経鼻胃管 は, 留置手技も簡便で, 胃液の吸引, 経管栄養などを 目的として, 消化器手術後のみならず日常臨床におい て広く使用されている．初期にはゴム性の経鼻胃管が 
使用され，1991年頃より柔らかく耐久性の優れたポリ ウレタンやシリコン性のものが開発され始めたが, コ スト面から現在は主として塩化ビニル性の経鼻胃管が 汎用されている2). 塩化ビニル性の経疄胃管は耐久性 に富む利点がある一方で，比較的硬く腸管損傷を起こ す可能性も指摘されている，胃管に起因する胃切除術 後の消化管穿孔は，過去本邦において13例が報告され ている ${ }^{3) \sim 6\}}$.

自験例を含めた 14 症例を涉猟すると，平均年齢は 56.3歳，男女比は10：4であった。十二指腸溑瘍穿孔 の1例を除く13例（92.9\%）が胃癌であった。術式は Billroth I 亜全摘術11例, Billroth II 亜全摘術 1 例, Roux-enY 全摘術 2 例であった。穿孔部位は残胃大慜 側が10例 $(71.4 \%)$ と最も多く，吻合部が 2 例，空腸 が 2 例であっだ).

残胃穿孔の診断は腹部 CT 検查, 腹部超音波検査に おいて漏出液の貯留を証明し，さらに残胃造影検查に て造影昘の胃外への漏出を確認することてなされる. 自験例では，術後 3 日目に施行した CT 検査にて膵背 側に腹水の貯留を認めたが少量であり,これを術後変 化と判断し，術後 5 日目の残胃造影検査にて残胃大彎 からの造影剤漏出により診断しえた。過去報告例では， 経鼻胃管留置から，穿孔までの平均期間は3.7日（1 〜 7 日) ${ }^{3)}$ と推定されており，比較的早期に起こると考 えられている. 自験例では術後より発熱が遷延し，1 日目に単純X線撮影にて胃管の左方偏位が認めら机， 2 日目にCRP 28.3と高值を示していることより, retrospective に考えて穿孔発症日は術後 1 日目と推定さ れた.

残胃穿孔の要因として, 福田ら゙3はリンパ節郭清に 伴う局所的血流障害や術後低蛋白血症による残胃浮 腫, 胃管の不適切な挿入位置を, 斉藤ら”は大網・小網 除去によるいわゆる裸のような環境を挙げている，症 状は比較的軽度で発熱が12例（85.7\%）で認められた が，腹痛は 2 例に認められたのみであり，無症状の症 例も報告されている゙!。自験例でも腹腔内に留置した ドレーンが効果的であったため腹部症状はそしかっ た。呀孔による腹膜刺激症状が急に出現しない可能性 のある術後状態においては，本病態の可能性を念頭に 置いた観察が必要と考えられた。

本病態に対する治療としては, 保存的加療が 9 例, ドレナージ術が 3 例, 穿孔部閉鎖+ドレナージ術が 2 例に行われている3!.このように多数の例では保存的 治療が可能であるが，膿瘍腔が大きい症例やドレナー
ジが不良である症例，さらには保存的治療に抵抗し， 発熱や炎症所見が持続する症例に対してはドレナージ 術等の外科的処置を踣躇せずに行うべきであると考え られる。

胃管による残胃穿孔を防止するために，術中残胃を 愛護的に扱うように心がけると同時に，閉腹に先立ち 胃管の先端が胃壁を強く圧迫することのないように注 意するべきである。また，術後は胃管の先端の位置を 腹部X線検㚗で確認し，必要に応じて先端の位置を修 正する必要がある。自験例では，閉腹前に胃管先端の 位置を確認し，胃壁および吻合部を圧迫せぬよう残胃 の中央に留置したが，術後結果的に残胃穿孔の直接的 原因となってしまった。術後 1 日目の腹部X線検査で は胃管の先端は左方を向いていた(図4)。この時点で 大顛側胃壁を圧迫していた可能性は十分あると考えら れ，胃管の先端の位置を修正する必要があったと反省 している.

胃切除術後の経鼻胃管留置の是非に関しては未だ一 定の見解は得られていない，当科においては，現在は クリニカルパス上で幽門側胃切除術後は術翌日に胃管 を抜去しているか，本報告例の診療時には胃管の抜去 時期は画一化されておらず，術後 $2 \sim 4$ 日間留置され る症例がほとんどであった。さらに術後経過中に炎症 反応の上昇などが認められた場合には，万が一の縫合 不全の可能性をも念頭に置き，胃管の留置を続行する のが通例であった，本病態の如き合併症を回避するた めには，胃管の不必要な長期留置を避けると同時に， 止むを得ず留置する場合には充分な注意が必要と考え られた。

おわりに

胃癌に対するBillroth I 法覀全摘術後に留置した 経悬胃管により残胃穿孔をきたした症例を報告した。

$$
\text { 文献 }
$$

1) Levin AL:A New Gastroduodenal Catheter. JAMA $76: 1007-1013,1921$

2）小野田尚佳, 鄭 容錫, 大平雅一他：内視鏡にて 確認しえた経鼻胃管による食道損傷の 1 例. Med Postgrad 29:324-328, 1991

3）福田淔人, 館花明彦, 土用下和之他：経舅胃管に よる胃切除後残胃穿孔の 1 例. 日腹部救急医会誌 $22: 103-106,2002$

4) 三須雄一郎, 策田徳三, 金井伸行他：胃切後の胃

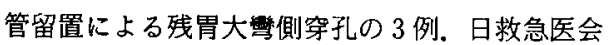
関東誌 $13: 580-581,1992$ 
5）石川 泰, 京極高久, 高峰義和他：胃切除術後に 留䈯された管による残周穿孔の 1 例. 日臨外会 誌 $61 ： 2008-2011,2000$

6) 岩佐 搏, 三村一夫, 加辺純雄他：消化器外科術
後の合併症とその対策. 外科殄療 $23 ： 1606-$ 1611,1981

7) 斉藤 光, 高橋康雄：胃手術後の留置胃ソンデの 危険性とその対策. 消外 $5: 333-340,1982$

\title{
A CASE OF RESIDUAL GASTRIC PERFORATION DUE TO A NASOGASTRIC TUBE FOLLOWING GASTRECTOMY
}

\author{
Satoshi KAINUMA, Shoki MIKATA, Toshikazu ITO, \\ Tsunekazu MIZUSHIMA, Kentaro NONAKA and Kazuhiro IWASE \\ Department of Surgery, Rinku General Medical Center, Izumisano Municipal Hospital
}

A 63-year-old man underwent distal gastrectomy with Billroth I reconstruction for type 3 gastric carcinoma localized at the body of the stomach. A nasogastric tube was inserted into the residual stomach. He developed a fever since the 2 nd postoperative day, and laboratory data were compatible with inflammatory disorders. Abdominal $\mathrm{CT}$ scans showed a small quantity of fluid which was considered to be caused by operative procedures. On the 5th postoperative day, purulent discharge through the intraabdominal drainage tube was recognized. Fluoroscopic examination using contrast media revealed penetration of the nasogastric tube through gastric wall and the extragastric discharge of the media at the greater curvature. Conservative treatment including total parenteral nutrition and antibiotics was performed because the intraabdominal drainage was assured by the drainage tube. Oral intake was started on the 34 th postoperative day. The patient was discharged without other complications on the 44th postoperative day. 